\title{
Life impact of ankle fractures: Qualitative analysis of patient and clinician experiences
}

Steven M McPhail ${ }^{1,2^{*}}$, Joel Dunstan ${ }^{3}$, Julie Canning ${ }^{2}$ and Terry P Haines ${ }^{4,5}$

\begin{abstract}
Background: Ankle fractures are one of the more commonly occurring forms of trauma managed by orthopaedic teams worldwide. The impacts of these injuries are not restricted to pain and disability caused at the time of the incident, but may also result in long term physical, psychological, and social consequences. There are currently no ankle fracture specific patient-reported outcome measures with a robust content foundation. This investigation aimed to develop a thematic conceptual framework of life impacts following ankle fracture from the experiences of people who have suffered ankle fractures as well as the health professionals who treat them.

Methods: A qualitative investigation was undertaken using in-depth semi-structured interviews with people $(n=12)$ who had previously sustained an ankle fracture (patients) and health professionals $(n=6)$ that treat people with ankle fractures. Interviews were audio-recorded and transcribed. Each phrase was individually coded and grouped in categories and aligned under emerging themes by two independent researchers.

Results: Saturation occurred after 10 in-depth patient interviews. Time since injury for patients ranged from 6 weeks to more than 2 years. Experience of health professionals ranged from 1 year to 16 years working with people with ankle fractures. Health professionals included an Orthopaedic surgeon (1), physiotherapists (3), a podiatrist (1) and an occupational therapist (1). The emerging framework derived from patient data included eight themes (Physical, Psychological, Daily Living, Social, Occupational and Domestic, Financial, Aesthetic and Medication Taking). Health professional responses did not reveal any additional themes, but tended to focus on physical and occupational themes.
\end{abstract}

Conclusions: The nature of life impact following ankle fractures can extend beyond short term pain and discomfort into many areas of life. The findings from this research have provided an empirically derived framework from which a condition-specific patient-reported outcome measure can be developed.

\section{Background}

Traumatic musculoskeletal injuries are a common problem that may result in short or long term pain and disability [1-5]. Fractures around the ankle are one of the more commonly occurring forms of trauma managed by orthopaedic teams worldwide with Australasian data citing an incidence of 43.5 fractures per 100,000 persons per year [6-8]. Despite their high incidence, ankle fractures may be considered by some to be a 'lesser' injury in comparison to other fractures (such as multiple

\footnotetext{
* Correspondence: steven_mcphail@health.qld.gov.au

${ }^{1}$ Centre for Functioning and Health Research, Metro South Health, Buranda Plaza, Corner Ipswich Road and Cornwall Street Buranda, Brisbane, Australia ${ }^{2}$ School of Public Health \& Social Work and Institute of Health and Biomedical Innovation, Queensland University of Technology, Kelvin Grove, Brisbane, Australia

Full list of author information is available at the end of the article
}

trauma, hip fractures or fractures of the axial skeleton) and have attracted less empirical research in comparison to other common fracture types [9-14]. This potential consideration of ankle fractures as a lesser injury may be due to a perception that ankle fractures are localised in nature and have a high success rate of fracture reduction and union with established treatment protocols $[9,15]$. However, any perception that ankle fractures have a low rate of sub-optimal outcome and negligible negative long term consequence are not founded in empirical data. Prior empirical research has indicated the impact of ankle fractures may not be restricted to pain and disability caused at the time of the incident but continue for an extended duration $[9,15]$.

Long term effects of ankle fractures have been reported to include physical, psychological, and social

\section{Biomed Central}


consequences [9]. It has been reported that physical impairments following ankle fractures may include pain, functional impairment and the development of posttrauma arthritis [16]. Negative psychological consequences following ankle fractures have been reported to include fatigue, depression, anxiety and sleep disturbances [9]. Negative social consequences have included difficulty returning to work and dependence on disability benefits [9]. These types of negative consequences are comparable to those that have been reported among other severe fracture types [13,17-20].

There is some controversy as to the proportion of patients who recover well following ankle fractures [21]. Some previous studies have identified that $52 \%$ to $87 \%$ of patients have good to excellent clinical outcomes after an ankle fracture [7,22-25]. In contrast, a number of follow-up studies looking at patient outcomes between 14 months and 6 years following fracture have found that few patients reported a full recovery in most areas $[8,9,26]$. Specifically, $52 \%$ of patients had psychological complaints due to the initial injury, [9] and 52\% had difficulties with sport activities [8]. Nilsson, Nyberg et al.[26] found that 51\% selfreport poor function with complaints of ongoing stiffness and swelling, pain with walking, and an impaired ability to climb stairs. A recent systematic review of long term outcomes from 1822 ankle fractures across 18 studies (4 to 14 years follow up) reported that approximately one in five did not result in a good or excellent outcome [15]. In these investigations, success was classified according to performance against a set of researcher-selected subjective symptoms and objective findings [15]. Additionally, measurement methodologies were frequently not described in detail or had not been tested for reliability and validity [15]. Insufficient or suboptimal rehabilitation has been cited as a potential cause of long-term disability in this population [26]. However, a Cochrane systematic review of ankle fracture rehabilitation in adults highlighted that limited evidence is available at present to inform specific rehabilitation protocols for clinical practice [27].

One limiting factor when planning and conducting research among people with ankle fractures is the absence of a suitable ankle fracture specific patient-reported outcome measure. The inclusion of patient-reported outcomes as primary measures has become increasingly common across a wide range of clinical and research settings [28-33]. Common patient-reported outcomes that are frequently used among people with musculoskeletal conditions include measures of pain [34-36], physical function activity limitations [37-39] and health-related quality of life [40-45]. The use of patient-reported outcomes permit clinicians and health researchers to evaluate the effectiveness of an intervention based on the lived experience of the person with the condition under consideration [35,46-48].

Condition-specific patient-reported outcome measures should reflect those areas of life that are meaningfully influenced by the condition under consideration from the perspective of the patient $[49,50]$. The areas of life influenced by the condition may extend beyond physical functioning activity limitations [9]. This is in contrast to clinically derived measures that may focus on constructs that health professionals consider to be important (such as changes detected in x-ray images, joint range of motion or clinical performance tests) [51-53]. A conditionspecific patient-reported outcome measure for use among ankle fracture patients during their rehabilitation should capture the effects of rehabilitation which patients (rather than health professionals) consider most important [49]. These effects must also be evaluated in a way that is valid, reliable and responsive to change over the entire rehabilitation period [54,55].

Investigations of ankle fracture rehabilitation included in a Cochrane systematic review of ankle fracture rehabilitation focused on clinical outcomes; including ankle range of motion and performance tests $[27,56]$. Some investigations used patient-reported outcomes to assess health professional defined physical activity limitations [57-62]. The most frequently used patientreported outcome for this purpose was the Olerud Molander Ankle Scale [27,63]. This scale was reported by Olerud and Molander in 1984 to improve the way ankle symptoms were evaluated [63]. The scale includes nine parameters focusing on physical symptoms and physical activities (walking, stiffness, swelling, stairclimbing, running, jumping, squatting, physical supports, and work capacity) [63]. The scale includes two to five multiple choice response options for each parameter which the authors of the scale assigned a value of 0,5 , $10,15,20$ or 25 (maximum total score is 100) [63]. While this scale is practical and represented advancement beyond describing ankle symptoms into overall subjective categories such as a 'good' or 'poor' outcome, the scale has been criticised for lacking a methodologically robust foundation with content and scores based on expert opinion alone [47]. There is also a marked lack of empirical evidence reporting favourable psychometric and clinimetric properties for this scale $[47,55,63,64]$.

Absence of a robust content foundation or empirical evidence indicating favourable clinimetric properties is also a shortcoming of other patient-reported outcomes for the foot and ankle [47,57-59,62,64]. Other patientreported measures identified in the Cochrane review of ankle rehabilitation included the Clinical Demerit Points (based on the Weber Protocol) [62], Lower Extremity Functional Scale (LEFS) [60,65], Inflammatory Score [61], Maryland Foot Score [59], a visual analogue scale 
[58] and a grading scale by Mazure in 1979 [57]. These measures lack a methodologically robust foundation for evaluating life impacts experienced by ankle fracture patients during their rehabilitation $[47,49]$. Their content and scoring are commonly based on expert opinion alone and tend to focus on physical symptoms or activity performance. With the exception of the LEFS, these measures also lack empirical support for key elements of validity, reliability and responsiveness [47,57-59,62,64].

The LEFS has demonstrated favourable clinimetric properties in non-ankle fracture populations [65-67], and during the acute phase of ankle fracture recovery [68]. However, the ceiling effect observed after the acute phase of ankle fracture rehabilitation is detrimental to its use as a primary outcome measure throughout the entirety of the rehabilitation process [68]. Additionally, the content (and subsequent scoring) of the LEFS focuses heavily on elements of performance related to physical tasks (including walking, squatting, running, standing, stairs, hopping) [65]. This is not necessarily a weakness for an instrument intended to assess patients' ratings of their lower extremity physical function. The LEFS has a solid foundation of empirical data supporting its use for this purpose $[65,67,69]$. However, the LEFS was not developed with an empirical foundation for use as an ankle fracture condition-specific patient-reported outcome measure intended to evaluate the life impacts (including non-physical impacts) that are most meaningful to patients recovering from an ankle fracture [9].

In summary, a range of patient-reported outcomes have been used among people with ankle fractures. These measures frequently have some methodological foundation in previous examinations of particular aspects of validity and reliability. However, ideally patient-reported outcomes should have foundation in patient-reported impacts, in addition to performing well in studies reporting aspects of validity, reliability and responsiveness to change. Including the patient's perspectives when evaluating ankle fracture interventions may be problematic in the absence of a condition-specific patient-reported outcome measure empirically derived from lived patient experiences [49]. Existing foot and ankle outcomes were designed to evaluate physical symptoms and activity performance across a range of lower limb conditions [47,63-65]. These measures are unlikely to capture the most salient physical and non-physical impacts experienced by people recovering from ankle fractures [9].

This study aimed to investigate the nature of life impacts following ankle fractures with the intention of describing a thematic conceptual framework based on these lived experiences of people who have suffered ankle fractures. The investigators considered the description of this thematic framework as a critical first step in the development of an ankle fracture specific, patient- reported outcome measure suitable for evaluating the impact of an ankle fracture on patients' lives. The development of such a measure into a questionnaire format would likely permit efficient and effective assessment of the impact of ankle fractures on patients' health-related quality of life (not just their physical activity limitations). A questionnaire for this purpose would have application in both clinical and research settings. This measure could have potential use at a single assessment or as a repeated measure to evaluate recovery (or decline) longitudinally. This would allow use in both observational and intervention studies; including clinical trials evaluating the effectiveness of ankle fracture rehabilitation protocols. Therefore, the purpose of this study was to not only investigate the nature of life impacts in the acute post-injury phase of recovery following ankle fractures, but to include life impacts across the recovery continuum and returning to work and usual daily living.

\section{Methods \\ Design}

Qualitative analyses of semi-structured interviews were undertaken. This design was selected as an appropriate modality to explore the range of perceived life impacts following ankle fractures founded on the lived experiences of patients who have suffered this injury.

\section{Participants and setting}

The targeted inclusion of patients from across the temporal breadth of recovery was employed to promote the inclusion of a diversity of life impacts across the entire rehabilitation period. To this end, purposive sampling of adults who had experienced an ankle fracture (patients) and health professionals who have experience treating patients with ankle fractures were recruited from a tertiary hospital facility. Patient participants were recruited to fill three strata (ratio of $1: 1: 1$ ) of time since ankle fracture from one to six months, from six months to two years and greater than two years. The investigators considered but decided against purposive sampling to ensure a range of fracture severities (in addition to temporal diversity) as prior research revealed negative consequences following ankle fracture were not necessarily dependent on the initial severity of fracture [15].

Health professionals from multiple discipline backgrounds were also interviewed to capture a range of health professional perspectives. While examining the opinion of health professionals was not the primary purpose of this investigation, the inclusion of health professionals who have seen many patients with ankle fractures was considered a feasible approach to add additional strength to the investigation. It was considered that health professionals may have been more likely to report an infrequent but severe life impact given their 
greater exposure to ankle fracture cases in comparison to patient participants. The authors considered that an echoing of some patient-reported life impacts by health professionals, without the addition of new categories or themes would lend weight to the reliability and validity of a thematic framework developed from patient responses. Purposive sampling was undertaken to ensure representation from four health professions who commonly make contributions to the management and rehabilitation of ankle fracture patients (orthopaedic surgery, physiotherapy, occupational therapy and podiatry). The investigators considered that the inclusion of at least one health professional from each of the four disciplines would be likely to add an additional degree of rigour to the development of the thematic framework.

\section{Recruitment}

Patient participants were recruited from flyer advertisements posted within the hospital facility where the study was conducted. Health professional participants were recruited from similar flyers posted in orthopaedic clinic locations, staff notice boards and promotion of the research at a clinical staff meeting. The flyers contained a brief description of the study and a contact details for a member of the investigative team. This team member explained the study to potential participants in detail, provided a study information and consent form, and answered any questions relating to the study.

\section{Interview content and procedure}

Consenting participants completed a single semistructured interview in a private office or clinical consultation room at the hospital. Interviews were audio-recorded and transcribed verbatim (pseudonym names were inserted and patient participant responses were coded with a unique identifying number to protect participant confidentiality). Audio files and transcripts were stored digitally. The duration of interviews ranged between 32 and 65 minutes. The same member of the research team conducted all patient interviews. This interviewer was a physiotherapist who had extensive experience working with orthopaedic patients in clinical settings (although was not directly involved in clinical management of any participants in this study).

The interview content for patients included four broad partitions; 1) demographic and injury description, 2) life impacts immediately following the ankle fracture, 3) life impacts at approximately 6 weeks post-fracture (or immediately after the cast was removed), and 4) life impacts at the present time. During the demographics and injury description, participants were asked to describe the injury (including when the injury had occurred), as well as a description of the treatment they received. This included whether or not surgery to stabilise the ankle fracture was performed and the nature of any post fracture rehabilitation undertaken. This information was collected to describe the sample and is presented in Table 1.

For the life impact portions of the interview (temporal partitions 2 to 4 outlined above), the investigators considered it possible that the interviewer's clinical physiotherapy background may have impacted on the content being unintentionally focused on physical impairments and biomechanical functioning. For this reason an interview schedule was constructed to ensure non-physical impacts were discussed and explored. An example of the stimulus questions from one temporal partition is displayed in Table 2. This same pattern of stimulus questions was used in each of the three partitions (2 to 4), but with reference to different stages of recovery following rehabilitation as appropriate. In addition to these initial stimulus questions, the interviewer was instructed to use probing questions to explore the nature of all types of impacts that the patient began to describe in response to the initial scheduled questions. The interview schedule was initially developed from prior research reporting potential negative consequences of ankle fractures and the research teams own experiences [9]. Additionally, the interview schedule was able to be adjusted in response to data from earlier interviews. However, only one minor refinement, the addition of a question about impact on life roles, was added after the first three interviews.

A different researcher conducted the health professional interviews. This researcher had not worked as a colleague in clinical settings with any of the health professionals and was not in a dependent professional relationship (e.g. superior-subordinate) with any health professional participants. The same interview structure was followed for the health professional participants.

\section{Analysis}

Qualitative analysis of interview transcripts for people who had experienced an ankle fracture was undertaken using thematic analysis [70,71]. Each phrase was coded and sorted into categories by two independent researchers. The categories were then grouped together with other related or similar categories. These emerging groups of related categories were then considered as an overarching theme that was subsequently described (based on the content of the categories and nature of the relationship between them). To support the rigour of this process, each of the two coders completed this task independently for each participant before meeting to compare their coding and emerging framework. A third independent researcher was available to mediate any unresolved coding disagreement between the two primary coders (for categories or emerging themes); however, no such disagreement occurred. 
Table 1 Demographic and fracture information from participants who suffered an ankle fracture

\begin{tabular}{|c|c|c|c|c|c|c|c|c|}
\hline $\begin{array}{l}\text { Participant } \\
\text { code }\end{array}$ & Gender & Age & $\begin{array}{l}\text { How ankle fracture } \\
\text { occurred }\end{array}$ & $\begin{array}{l}\text { Bones } \\
\text { fractured }\end{array}$ & $\begin{array}{l}\text { Any other injury at time } \\
\text { of fracture }\end{array}$ & $\begin{array}{l}\text { Surgical } \\
\text { fixation of } \\
\text { ankle fracture }\end{array}$ & $\begin{array}{l}\text { Weeks participating } \\
\text { in rehabilitation } \\
\text { therapies }\end{array}$ & $\begin{array}{l}\text { Time since } \\
\text { injury } \\
\text { strata }\end{array}$ \\
\hline P1 & Female & 58 & Tripped over pet dog & Distal fibula & no & None & 4 & $\begin{array}{l}>24 \\
\text { months }\end{array}$ \\
\hline P2 & Male & 38 & $\begin{array}{l}\text { Car accident (car } \\
\text { versus car) }\end{array}$ & $\begin{array}{l}\text { Distal tibia } \\
\text { and distal } \\
\text { fibula }\end{array}$ & no & ORIF* & 8 & $\begin{array}{l}>24 \\
\text { months }\end{array}$ \\
\hline P3 & Male & 19 & $\begin{array}{l}\text { Dropped while } \\
\text { 'crowd surfing' }\end{array}$ & Distal fibula & no & ORIF & 4 & $\begin{array}{l}\text { Between } 6 \\
\text { and } 24 \\
\text { months }\end{array}$ \\
\hline P4 & Male & 30 & $\begin{array}{l}\text { Motor bike accident } \\
\text { (bike versus car) }\end{array}$ & $\begin{array}{l}\text { Distal tibia } \\
\text { and distal } \\
\text { fibula }\end{array}$ & $\begin{array}{l}\text { Haematoma adjacent to } \\
\text { ipsilateral knee (resolved } \\
\text { spontaneously) }\end{array}$ & ORIF & 13 & $\begin{array}{l}\text { Between } 6 \\
\text { and } 24 \\
\text { months }\end{array}$ \\
\hline P5 & Female & 49 & $\begin{array}{l}\text { Ankle twist injury } \\
\text { playing sport (netball) }\end{array}$ & Distal fibula & no & None & 0 & $\begin{array}{l}>24 \\
\text { months }\end{array}$ \\
\hline P6 & Female & 24 & Hiking (slip and fall) & Distal fibula & no & None & 6 & $\begin{array}{l}>24 \\
\text { months }\end{array}$ \\
\hline P7 & Female & 45 & Fell off horse & $\begin{array}{l}\text { Distal tibia } \\
\text { and distal } \\
\text { fibula }\end{array}$ & no & ORIF & 5 & $\begin{array}{l}<6 \\
\text { months }\end{array}$ \\
\hline P8 & Female & 47 & $\begin{array}{l}\text { Fall walking in } \\
\text { platform shoes on } \\
\text { uneven surface }\end{array}$ & Distal fibula & no & ORIF & 4 & $\begin{array}{l}<6 \\
\text { months }\end{array}$ \\
\hline P9 & Female & 28 & $\begin{array}{l}\text { Skiing (collision and } \\
\text { fall) }\end{array}$ & Distal fibula & no & None & 11 & $\begin{array}{l}<6 \\
\text { months }\end{array}$ \\
\hline P10 & Male & 32 & $\begin{array}{l}\text { Motor bike accident } \\
\text { (clipped curb on side } \\
\text { of road) }\end{array}$ & $\begin{array}{l}\text { Distal tibia } \\
\text { and distal } \\
\text { fibula }\end{array}$ & no & ORIF & 7 & $\begin{array}{l}<6 \\
\text { months }\end{array}$ \\
\hline P11 & Male & 29 & $\begin{array}{l}\text { Tackled playing } \\
\text { football (soccer) }\end{array}$ & $\begin{array}{l}\text { Distal tibia } \\
\text { and distal } \\
\text { fibula }\end{array}$ & no & ORIF & 0 & $\begin{array}{l}\text { Between } 6 \\
\text { and } 24 \\
\text { months }\end{array}$ \\
\hline P12 & Male & 23 & Wakeboarding injury & Distal fibula & no & None & 3 & $\begin{array}{l}\text { Between } 6 \\
\text { and } 24 \\
\text { months }\end{array}$ \\
\hline
\end{tabular}

*Open Reduction Internal Fixation (ORIF).

When a single phrase contained multiple life impacts that aligned with one or more categories, each relevant component was coded separately and grouped appropriately. Data saturation was considered to have occurred when 2 consecutive patient interviews did not add any additional categories or themes to the emerging framework. After the thematic framework was developed from patient data (Table 3), this coding process was repeated for the transcripts of health professionals who treat people with ankle fractures. However, the categories from health professionals were aligned under the thematic framework developed from the responses of

Table 2 Example stimulus questions from a single partition of the semi-structured interview

\begin{tabular}{ll}
\hline $\begin{array}{l}\text { Question } \\
\text { number }\end{array}$ & Stimulus question \\
\hline 1 & How was your ankle at the time? \\
3 & How did that make you feel? \\
4 & Were there any things that concerned you about your ankle when you were using it? \\
5 & How did your ankle affect your ability to complete everyday activities around your house? \\
6 & How did your ankle affect your ability to complete your occupation? \\
7 & How did your ankle affect your ability to complete your leisure activities? \\
& participated in?
\end{tabular}


Table 3 Thematic conceptual framework of life impacts following ankle fractures, including categories represented within each theme

\begin{tabular}{|c|c|c|c|c|c|c|c|}
\hline Physical & Psychological & Daily living & Social & $\begin{array}{l}\text { Occupational } \\
\text { or Domestic }\end{array}$ & Financial & Aesthetic & $\begin{array}{l}\text { Medication } \\
\text { Taking }\end{array}$ \\
\hline $\begin{array}{l}\text { Physical impacts } \\
\text { experienced }\end{array}$ & $\begin{array}{l}\text { Psychological } \\
\text { impacts } \\
\text { experienced }\end{array}$ & $\begin{array}{l}\text { Impacts on daily living } \\
\text { activities }\end{array}$ & $\begin{array}{l}\text { Social impacts } \\
\text { experienced }\end{array}$ & $\begin{array}{l}\text { Impacts on } \\
\text { occupational } \\
\text { or domestic } \\
\text { tasks }\end{array}$ & $\begin{array}{l}\text { Financial } \\
\text { impacts } \\
\text { experienced }\end{array}$ & $\begin{array}{l}\text { Aesthetic } \\
\text { impacts } \\
\text { experienced }\end{array}$ & $\begin{array}{l}\text { Experiences } \\
\text { associated with } \\
\text { medications }\end{array}$ \\
\hline $\begin{array}{l}\text { 1. Pain, ache, } \\
\text { soreness or } \\
\text { discomfort }\end{array}$ & $\begin{array}{l}\text { 1. Feelings of } \\
\text { anxiety }\end{array}$ & $\begin{array}{l}\text { 1. Reduced participation } \\
\text { in preferred recreation } \\
\text { or leisure activities }\end{array}$ & $\begin{array}{l}\text { 1. Negative impact } \\
\text { on relationship } \\
\text { with spouse or } \\
\text { significant other }\end{array}$ & $\begin{array}{l}\text { 1. Difficulty } \\
\text { participating } \\
\text { in usual work } \\
\text { activity }\end{array}$ & $\begin{array}{l}\text { 1. Reduced } \\
\text { income }\end{array}$ & $\begin{array}{l}\text { 1. Changed } \\
\text { physical } \\
\text { appearance } \\
\text { due to weight } \\
\text { gain. }\end{array}$ & $\begin{array}{l}\text { 1. Medication } \\
\text { usage } \\
\text { (including } \\
\text { associated side } \\
\text { effects) }\end{array}$ \\
\hline 2. Swelling & $\begin{array}{l}\text { 2. Feelings of } \\
\text { depression }\end{array}$ & $\begin{array}{l}\text { 2. Reduced participation } \\
\text { in health and fitness } \\
\text { activities }\end{array}$ & $\begin{array}{l}\text { 2. Increased } \\
\text { dependence on } \\
\text { others in } \\
\text { household }\end{array}$ & $\begin{array}{l}\text { 2. Difficulty } \\
\text { completing } \\
\text { household } \\
\text { tasks }\end{array}$ & $\begin{array}{l}\text { 2. Use of } \\
\text { savings }\end{array}$ & $\begin{array}{l}\text { 2. Now wear } \\
\text { non-preferred } \\
\text { footwear }\end{array}$ & \\
\hline $\begin{array}{l}\text { 3. Decreased } \\
\text { strength }\end{array}$ & $\begin{array}{l}\text { 3. Feelings of } \\
\text { frustration }\end{array}$ & $\begin{array}{l}\text { 3. Difficulty participating } \\
\text { in personal care } \\
\text { activities (including } \\
\text { showering and dressing) }\end{array}$ & $\begin{array}{l}\text { 3. Negative impact } \\
\text { on personal } \\
\text { relationships with } \\
\text { family or friends. }\end{array}$ & & $\begin{array}{l}\text { 3. Reduced } \\
\text { discretionary } \\
\text { spending }\end{array}$ & & \\
\hline $\begin{array}{l}\text { 4. Decreased } \\
\text { range of } \\
\text { movement/ } \\
\text { stiffness }\end{array}$ & $\begin{array}{l}\text { 4. Feelings of } \\
\text { tiredness or } \\
\text { fatigue }\end{array}$ & 4. Difficulty sleeping & & & $\begin{array}{l}\text { 4. Increased } \\
\text { cost of living } \\
\text { (including } \\
\text { healthcare } \\
\text { costs) }\end{array}$ & & \\
\hline \multicolumn{8}{|l|}{$\begin{array}{l}\text { 5. Altered } \\
\text { sensation }\end{array}$} \\
\hline $\begin{array}{l}\text { 6. Difficulty } \\
\text { walking } \\
\text { (including flat } \\
\text { surfaces, slopes } \\
\text { and steps) }\end{array}$ & & & & & & & \\
\hline
\end{tabular}

people who had experienced an ankle fracture (where appropriate). New categories or themes from the health professionals' responses (not yet represented) could be added to the emerging framework as indicated.

Within each theme, the prominent emerging category or categories were identified based on the frequency and nature of responses (with many similar or related responses indicating a primary emerging category). These prominent categories for life impacts following ankle fractures are discussed in the text of the results section separately for patients and health professionals.

\section{Ethics}

This investigation conformed to the Declaration of Helsinki and local legislation. The investigation was approved by the Princess Alexandra Hospital human research ethics committee and undertaken within the bounds of national ethical guidelines.

\section{Results}

Thirteen patients and six health professionals were invited to participate in the investigation after responding to the study advertisement (and being deemed appropriate in meeting one of the required purposive sampling strata). However, one patient was not able to find a suitable time to schedule an interview, so declined participation. Twelve patient interviews and six health professional interviews were undertaken and included in analysis. Patient demographic and clinical information, including a brief summary of patients' descriptions of their ankle fractures are presented in Table 1. The sample included diverse causes of ankle fracture and patient ages. There was equal gender representation. Seven patients reported receiving surgical stabilisation (each of these descriptions consistent with open reduction, internal fixation). Health professionals included an Orthopaedic surgeon (1), physiotherapists (3), a podiatrist (1) and an occupational therapist (1). Experience of health professionals ranged from 1 year to 16 years working with people with ankle fractures.

Data saturation occurred after ten patient interviews; with the final two patient interviews not contributing any further themes or categories. Data saturation being reached after only ten interviews may have occurred due to inclusion of patients who had experienced diverse and severe impacts following their ankle fracture. The rich and somewhat exhaustive data contributed by these patients covered a large proportion of categories 
included in the final thematic framework. The final framework is presented in Table 3. The eight emerging themes included Physical, Psychological, Daily Living, Social, Occupational and Domestic, Financial, Aesthetic and Medication Taking. The six health professional interviews were coded to this framework (Table 3) without addition of any further themes or categories. Phrases from the health professional participants were most frequently aligned under categories in the Physical or Occupational theme; few were aligned under the Psychological, Aesthetic or Social themes. Example quotes for each of the eight themes are also presented in Table 4. These quotes were selected being as representative of the overarching theme and diversity of life impacts across the patient sample.

\section{Theme 1: physical}

A broad range of physical impacts were described by both patients and health professionals. These impacts included mechanical elements (swelling, reduced muscle strength, decreased range of motion) and associated afferent impacts (pain, discomfort, altered sensation etc.). Responses that described difficulty with walking without reference to any specific occupational or daily living impact were also grouped into this theme. For example, one participant noted "I am limited on how far (and) fast... I can walk" (p6). Impacts in this theme were not limited to the immediate post-fracture period: "it was (many) months before I got the movement back" (p10).

Pain was the primary emerging category reported by patients in this theme. Patient participants reported "pain was the number one problem" (p1). Immediately after the fracture and following the removal of the plaster, participants recalled substantial pain in their ankle. The present level of pain amongst the patient participants (of varying duration since injury) was heterogeneous with some reporting constant or daily pain; others described how the pain "just got better over time" (p5). Swelling was

Table 4 Examples of participant quotes from each theme in the conceptual framework

\begin{tabular}{|c|c|c|c|c|c|c|c|}
\hline Physical & Psychological & Daily living & Social & $\begin{array}{l}\text { Occupational } \\
\text { and Domestic }\end{array}$ & Financial & Aesthetic & $\begin{array}{l}\text { Medication } \\
\text { Taking }\end{array}$ \\
\hline $\begin{array}{l}\text { Physical } \\
\text { impacts } \\
\text { experienced }\end{array}$ & $\begin{array}{l}\text { Psychological } \\
\text { impacts } \\
\text { experienced }\end{array}$ & $\begin{array}{l}\text { Impacts on } \\
\text { daily living } \\
\text { activities }\end{array}$ & $\begin{array}{l}\text { Social impacts } \\
\text { experienced }\end{array}$ & $\begin{array}{l}\text { Impacts on } \\
\text { occupational or } \\
\text { domestic tasks }\end{array}$ & $\begin{array}{l}\text { Financial impacts } \\
\text { experienced }\end{array}$ & $\begin{array}{l}\text { Aesthetic impacts } \\
\text { experienced }\end{array}$ & $\begin{array}{l}\text { Experiences } \\
\text { associated with } \\
\text { medications }\end{array}$ \\
\hline $\begin{array}{l}\text { "Very sore. } \\
\text { Pain was the } \\
\text { number one } \\
\text { problem."p1 }\end{array}$ & $\begin{array}{l}\text { "I was scared I } \\
\text { was going to } \\
\text { break it } \\
\text { again. .."p6 }\end{array}$ & $\begin{array}{l}\text { "No leisure. No } \\
\text { Sports. } \\
\text { Nothing."p12 }\end{array}$ & $\begin{array}{l}\text { "Personal life is } \\
\text { restricted with } \\
\text { relationships..."p9 }\end{array}$ & $\begin{array}{l}\text { "It causes me } \\
\text { pain. . but it } \\
\text { doesn't stop me } \\
\text { from working, } \\
\text { but I am in } \\
\text { more pain."p6 }\end{array}$ & $\begin{array}{l}\text { "I was out of work } \\
\text { so it affected } \\
\text { money."p11 }\end{array}$ & $\begin{array}{l}\text { "I haven't been } \\
\text { able to wear any } \\
\text { of my high heel } \\
\text { shoes."p8 }\end{array}$ & $\begin{array}{l}\text { "It causes me } \\
\text { pain- have to take } \\
\text { medication..."p12 }\end{array}$ \\
\hline $\begin{array}{l}\text { "Mainly if I } \\
\text { stand on it too } \\
\text { much, the } \\
\text { ankle gets } \\
\text { quite irritated } \\
\text { and very } \\
\text { swollen."p2 }\end{array}$ & $\begin{array}{l}\text { "I felt anxious } \\
\text { about putting } \\
\text { weight on } \\
\text { it. . . even } \\
\text { after the } \\
\text { doctor said I } \\
\text { could."p9 }\end{array}$ & $\begin{array}{l}\text { "I wasn't able } \\
\text { to do any } \\
\text { running..."p5 }\end{array}$ & $\begin{array}{l}\text { "(My wife) and I } \\
\text { ended up } \\
\text { arguing. .."p2 }\end{array}$ & $\begin{array}{l}\text { "...। } \\
\text { commenced on } \\
\text { light duties at } \\
\text { work."p2 }\end{array}$ & $\begin{array}{l}\text { "I had a fairly good } \\
\text { deposit for a } \\
\text { house. . . over the } \\
\text { past } 12 \text { months I } \\
\text { have slowly eaten } \\
\text { away my savings } \\
\text { account."p10 }\end{array}$ & $\begin{array}{l}\text { "The only problem } \\
\text { I had was just } \\
\text { fitting into } \\
\text { shoes... I wanted } \\
\text { to wear high heel } \\
\text { shoes to my } \\
\text { daughters } \\
\text { wedding..."p1 }\end{array}$ & $\begin{array}{l}\text { "the pills make } \\
\text { me feel sick"p6 }\end{array}$ \\
\hline $\begin{array}{l}\text { "It was weak } \\
\text { because one } \\
\text { leg was } \\
\text { skinnier than } \\
\text { the other... it } \\
\text { felt like it } \\
\text { might give } \\
\text { way."p12 }\end{array}$ & $\begin{array}{l}\text { "Emotionally I } \\
\text { was affected. I } \\
\text { used to feel } \\
\text { quite } \\
\text { depressed } \\
\text { and down a } \\
\text { lot. .."p10 }\end{array}$ & $\begin{array}{l}\text { "Could not do } \\
\text { anything. } \\
\text { Could not } \\
\text { even walk the } \\
\text { dog, too } \\
\text { painful."p1 }\end{array}$ & $\begin{array}{l}\text { "... virtually can't } \\
\text { socialize } \\
\text { anymore."p3 }\end{array}$ & $\begin{array}{l}\text { "I didn't do } \\
\text { much around } \\
\text { the house. I } \\
\text { couldn't house } \\
\text { clean."p5 }\end{array}$ & $\begin{array}{l}\text { "... and I had to } \\
\text { keep paying for } \\
\text { those tablets they } \\
\text { had me on."p4 }\end{array}$ & $\begin{array}{l}\text { "I put on } 5-6 \mathrm{~kg} \text { by } \\
\text { just sitting } \\
\text { around. . I I was } \\
\text { restricted by being } \\
\text { stuck on my } \\
\text { bed..."p4 }\end{array}$ & $\begin{array}{l}\text { "... I had to start } \\
\text { taking sleeping } \\
\text { tablets"p2 }\end{array}$ \\
\hline $\begin{array}{l}\text { "... I was very } \\
\text { limited in my } \\
\text { (ankle) } \\
\text { movements"p4 }\end{array}$ & $\begin{array}{l}\text { "it took so } \\
\text { long. . . it was } \\
\text { very } \\
\text { frustrating"p4 }\end{array}$ & $\begin{array}{l}\text { "I don't go to } \\
\text { soccer any } \\
\text { more. At all. I } \\
\text { haven't been } \\
\text { there."p11 }\end{array}$ & $\begin{array}{l}\text { "Your social life is } \\
\text { affected in a way } \\
\text { that you don't } \\
\text { want to go } \\
\text { out..."p6 }\end{array}$ & $\begin{array}{l}\text { "If it was sore, I } \\
\text { didn't want to } \\
\text { go to (work), so } \\
\text { I didn't go"p8 }\end{array}$ & $\begin{array}{l}\text { "I can't date } \\
\text { because I can't get } \\
\text { out and about and } \\
\text { I can't afford to } \\
\text { date."p12 }\end{array}$ & $\begin{array}{l}\text { "I have put on } \\
\text { weight as a result } \\
\text { of the fracture."p6 }\end{array}$ & $\begin{array}{l}\text { "I needed some } \\
\text { pain meds for a } \\
\text { few weeks, but } \\
\text { then it was } \\
\text { fine"p5 }\end{array}$ \\
\hline $\begin{array}{l}\text { "I could only } \\
\text { walk for a } \\
\text { certain } \\
\text { amount of } \\
\text { time before it } \\
\text { hurt."p5 }\end{array}$ & $\begin{array}{l}\text { "It was more } \\
\text { effort to do } \\
\text { anything, I felt } \\
\text { so tired all the } \\
\text { time..."p8 }\end{array}$ & $\begin{array}{l}\text { "I took on a } \\
\text { lesser role... I } \\
\text { modified the } \\
\text { activity so it } \\
\text { was less } \\
\text { demanding on } \\
\text { the } \\
\text { ankle..."p2 }\end{array}$ & $\begin{array}{l}\text { "My daughter got } \\
\text { annoyed (with } \\
\text { me) cause I } \\
\text { needed her to } \\
\text { drive me..."p1 }\end{array}$ & $\begin{array}{l}\text { "I have had to } \\
\text { change my job } \\
\text { entirely because } \\
\text { of my ankle } \\
\text { injury. . I I am } \\
\text { now not doing } \\
\text { anything."p10 }\end{array}$ & $\begin{array}{l}\text { "... anything that I } \\
\text { want to do } \\
\text { outside of sitting } \\
\text { in the lounge } \\
\text { room costs me } \\
\text { money I don't } \\
\text { have."p3 }\end{array}$ & $\begin{array}{l}\text { "... I now wear } \\
\text { these silly slip-ons } \\
\text { (shoes) } \\
\text { everywhere."p7 }\end{array}$ & $\begin{array}{l}\text { "...the tablets at } \\
\text { the start made } \\
\text { me sleep a lot"p2 }\end{array}$ \\
\hline
\end{tabular}


also identified as a major concern for patients, particularly immediately following plaster removal.

Health professional responses were focused within the physical impacts theme more than any other. Health professionals identified pain as a primary impact of the ankle fracture that may not resolve after the initial postfracture period. One health professional stated most of the patients are usually "feeling quite a bit of pain" (hp1) during the early post-fracture period another stated "...pain is still a problem months after the cast (is) off for some (patients)" (hp4). Health professionals were generally more articulate with their responses in this theme than patients. One health professional noted "...restricted dorsi flexion is usually a problem" (hp4) not only identifying restricted range of movement, but also commenting on a specific direction of movement commonly affected. Health professionals reported that swelling will be present, can be persistent and often causes discomfort.

\section{Theme 2: psychological}

Participants reported a range of psychological and emotional impacts attributed to their ankle fracture that were grouped into this theme. These included depression, anxiety, frustration and tiredness or fatigue. Responses grouped into this theme were often described in relation to another impact. For example "I was just so frustrated (that) it ached no matter what I did,"(p10) and "...ongoing pain just wore me out... I felt tired all the time" (p8).

The severity of psychological impacts reported by patients was not consistent across respondents. Responses from patients about feelings of depression ranged from being "...at an all time low in my life..." (p10) to ". . it is a bit depressing" (p2). Most participants stated that negative feelings resolved as they were able to return to activities undertaken prior to their ankle fracture. However, some participants reported ongoing unresolved anxiety or depression months after plaster removal. A participant who had experienced a difficult recovery after fracturing his ankle 18 months earlier stated he tended to "feel quite depressed and down a lot, and dwell on what happened and keep replaying things in (his) mind" (p10).

Health professionals infrequently described impacts that were aligned in this theme. Despite fewer responses in this theme, the impacts described were consistent with those described by patients. One health professional noted ". . some get a bit depressed about their situation" (hp5). Another recalled working with patients who had become anxious about the risk of re-fracturing the ankle despite $\mathrm{x}$-ray evidence of sound healing and reassurance from the health professional that fracture recurrence was not likely.

\section{Theme 3. daily living}

The primary emerging category in the daily living theme was the impact on participation in preferred recreation or leisure activities. Participants reported many of the recreational and leisure activities they had participated in prior to the ankle fracture were not possible or had to be modified following the ankle fracture. Both patients and health professionals reported substantial impacts on health and fitness activities. Impacts on personal care tasks were generally described in the context of the early post fracture period, as were difficulties with sleeping.

Many patient participants stated they could still do aspects of their previous activities after sustaining the ankle fracture, but needed to alter these as a result of the fracture. For example one participant was still able to go swimming, but was not able to use a flipper since the fracture. Another participant stated "I modified the activities I do so it's less demanding on the ankle but still enjoyable' (p2). Some had stopped participating in recreation or fitness related activities altogether due to ankle fracture reporting they felt they "couldn't do anything" (p12). Patient participants reported their ability to go walking or running was decreased, with one participant stating he was still unable to return to jogging almost a year post ankle fracture. Another stated "I can now only go walking (for) about one and half kilometres... I used to walk $5 \mathrm{~km}$ (regularly)" (p7).

Health professionals described a range of impacts in this theme that were congruent with responses from patients. They similarly reported substantial impacts on health and fitness activities as well as a range of impacts grouped into the other three categories in this theme (Table 3). However, at least one health professional felt that some patients continued to avoid physical activity long after there was any anatomical indication to do so. They reported this often occurred despite reassurance that it was not only safe, but beneficial to return to living a healthy active lifestyle. The health professionals also commented that many patients have unrealistic expectations about how quickly their ankle will heal and they will be able to return to their usual activities. With one stating "patients often think their ankle will get better quicker than it does" (hp2).

\section{Theme 4: social}

Impacts that were grouped within the social theme were diverse. In summary, they included the ability to undertake informal social activities with friends or family as well as reduced participation in formal social gatherings. Reports of the impact of their ankle fracture on ability to socialize differed across participants. Some stated that they had felt a decreased ability to be able to socialize with friends whereas as one patient stated they could still "hang out with people" (p3) and they actually spent 
more time with their friends than prior to their ankle fracture.

Some patients reported that they could not participate in many social activities so there was no point attending social gatherings. One participant reported staying home so she could keep her foot elevated instead of seeing friends. A number of participants felt they were a burden to friends and family. One patient stated he "felt like (he) let (his) wife down" (p2) and that it had negatively impacted their relationship. Participants reported they did not want to be "a drag or pain" ( 1 1) to their friends or family.

Health professionals infrequently reported responses in this theme. They did however note the increased burden for family members who may be required to assist older adults who have fractured their ankle and have difficulty with certain tasks. One health professional also noted that some patients resist becoming dependent on others in their household, even for a short period, while others seem more than happy for this to occur.

\section{Theme 5: occupational or domestic}

Both patients and health professionals reported impacts on a range of tasks included in this theme. These tasks included those involved with maintaining a household, paid employment or volunteer work. Some impacts reported in this theme were short lived and resolved after the initial post-fracture recovery and return to gait without the use of walking aids. Other impacts were long lasting and resulted in a career change for some.

The most frequent impact reported by patients was the need for light or modified duties at work and a reduction in home duties. Light or modified tasks at work had a major impact on most participants. Many reported that they "...could not work fulltime" (p1) and were restricted in their ability to work in the immediate postfracture period. Many participants stated that everyday domestic activities were very difficult to do and that many "didn't do much housework" (p9). Some participants who had returned to normal gait reported they were currently experiencing no limitation with occupational and domestic tasks stating their ankle is "no problem" ( $\mathrm{p} 5$ ) and "has no effect at all" (p9) on current occupational and domestic tasks. In contrast, another participant stated "I did not work for eleven and a half months... I ceased (my occupation) at that time" (p10). That participant had subsequently changed occupations to a less physically demanding role.

The severity of impact on work activities reported by health professionals varied widely. Health professionals reported that some patients had changed occupations after the ankle fracture due to the specific physical demands of their role. One health professional noted this seemed to happen more often when the patient worked in a "manual labour intensive" (hp6) role in the immediate pre-fracture period. Health professionals reported that impacts on occupational and domestic roles were usually short-lived and most people returned to pre-fracture roles within the first few months following the fracture.

\section{Theme 6: financial impact}

Responses in this theme included the financial impacts that were directly attributed to the ankle fracture. Responses focused on reduced income due to time off work, reduced work hours or an altered work role. An associated impact was the use of savings to compensate for reduced income or greater expenses (including expenditure on healthcare costs).

Patients reported financial impacts of mixed severity. Participants frequently reported reduced income as the primary financial impact. Many participants stated they were "out of work so it affected money" (p11) or suffered "loss of income as (I was) unable to work at full capacity for some months" (p2). However, patients also reported financial impacts that included reliance on savings and being forced to reduce their discretionary spending to compensate for the reduced income.

Health professionals frequently described impacts on paid employment activities. However, they did not extend this to include a description of personal financial implications.

\section{Theme 7: aesthetic impact}

Responses grouped into the aesthetic theme included those that related to physical appearance, rather than function or other health attributes. Two distinct categories emerged in this theme; weight gain and having to wear non preferred footwear. Some responses about weight gain were discussed by patients in the context of health and fitness (and grouped into the health and fitness category), rather than under the Aesthetic Impact theme.

Patients reported impacts from footwear limitations and concerns with their appearance following weight gain they had attributed to the ankle fracture. Limitations with footwear were identified by almost all the female patient participants, and this was usually connected to the inability to wear high heels. One participant stated "I wanted to wear high heel shoes to my daughters wedding... so I got quite upset when... (I) couldn't wear high heels to (my) daughter's wedding" (p1). Footwear comments were not limited to female participants or to high heels. One male participant reported "I couldn't just wear flip flops (uncovered recreational footwear)." A number of patient participants reported impacts on their appearance or clothing choices due weight gain since fracturing their ankle. One 
participant reported "I was (a little) bit concerned about how I looked..."(p6) after she "...had put weight on" (p6).

Health professionals described weight gain as an impact experienced by some patients as a result of reduced physical activity following their ankle fracture. However, this was raised in the context of health and fitness rather than an aesthetic impact. Health professionals infrequently identified difficulty for their patients in wearing preferred footwear in the immediate post ankle fracture period. It was stated by one health professional that those patients who suffered an ankle fracture "may not be able to wear high heeled shoes" (hp1).

\section{Theme 8: medication taking}

Comments in this theme included impacts relating to medication usage. Both patients and health professionals infrequently reported responses that were grouped into this category. Descriptions of life impacts reported in this theme tended to be focused on pain medication usage in the first few months after the ankle fracture and plaster removal. However, some comments grouped into this theme were also mentioned in the context of sleeping (Table 3).

\section{Discussion}

\section{Main finding}

This investigation has successfully indentified a broad range of life impacts reported from the lived experiences of people who have suffered an ankle fracture. It has been the first to report an empirically derived thematic framework highlighting that the impacts of ankle fractures extend beyond short term pain and discomfort. The eight themes included in the framework were Physical, Psychological, Daily Living, Social, Occupation and Domestic, Financial, Aesthetic and Medication Taking (Table 3) impacts. Objective measures of impairment commonly used in clinical assessments for people with ankle fractures match life impacts reported in the Physical theme (including joint range of motion, pain and swelling) [57-62]. The framework developed from this study suggests patient-reported life impacts follow ankle fractures extend beyond physical impairment into many facets of life. Constructs identified by this study that are frequently not represented in existing instruments used among people with ankle fractures include those relating to Psychological, Social, Financial, Aesthetic and Medicine Taking impacts [57-62]. A patient-reported outcome measure that assesses these wider impacts would be a pragmatic approach for assessing broad impacts and subsequent recovery after ankle fractures.

The nature of life impacts described by health professionals were congruent with those reported by patients. However, health professionals' responses focussed on physical and occupational impacts. This is not surprising given the nature of their routine interactions with people with ankle fractures. These interactions frequently focus on physical impairments, acute management and rehabilitation to return to daily living, occupational and domestic activities. Health professionals in this study also demonstrated some awareness of the broader impacts represented across the framework (Table 3), but did not discuss them in the same detail or with the same frequency as patient participants. Use of a patientreported outcome that evaluates these broader life impacts may assist health professionals and researchers to gain a deeper understanding of patients' recovery and identify when intervention for an associated life impact may be warranted (such as anxiety or depression) [72].

This investigation was an explorative study to formulate a framework of life impacts following ankle fractures. The study was not intended to investigate prevalence, prediction rules or associations between each of the life impacts. However, from participant responses it is clear that the severity and duration of life impacts reported varied widely across participants and themes. This variation is likely due to a range of factors including initial post-fracture management, anatomical alignment (or misalignment), post stabilisation rehabilitation and other personal attributes. It is also likely that the severity and duration of physical impacts are associated with other areas of life dependent on normal ankle functioning (such as routine health and fitness activities). These postulations are worthy of empirical research in order to justify whether more holistic interventions for people with ankle fractures are warranted.

There are two immediate implications from this study for the clinical management of patients with ankle fractures that are worthy of further consideration. First, multi-disciplinary care may be warranted in some cases. This is perhaps more likely to be true when the outcome of initial management was sub-optimal. Patients who end up suffering from diverse negative life impacts (depression, unemployment, chronic musculoskeletal pain, domestic difficulties etc.) may benefit from multidisciplinary input in order to improve their recovery and optimise their health-related quality of life. Second, health professionals caring for patients recovering from ankle fractures should consider whether a change in their own practice is required in order to mitigate the risk of some impacts (e.g. chronic pain) that may be able to be addressed within available treatment options. Another consideration may be whether there is scope to improve communication between health professionals and patients regarding the likely pathway and timeline of recovery. This may also include discussion of active patient participation in their recovery through therapies or return to work programs. However, in the absence of 
clinical trials establishing the efficacy of various post ankle fracture rehabilitation protocols, it is difficult to draw further firm clinical implications or recommend practice change based on the qualitative data generated in this study.

Comparison to prior research is difficult as this has been the first qualitative study of this nature undertaken amongst people with ankle fractures. However, findings from this research are consistent with previous reports of physical impairments (including pain and functional impairment), psychological consequences (including depression and anxiety) and negative social consequences (including difficulty returning to work) among people who had experienced ankle fractures [9]. These types of negative consequences are also comparable to those that have been reported among other severe fracture types and painful musculoskeletal disorders [13,17-20]. Findings from this research are also consistent with previous investigations that have indicated incomplete recovery can affect patients for long periods of time after acute fracture stabilisation and bone union has occurred $[8,9,26]$.

\section{Strengths and limitations}

There are several limitations and strengths to this research. First, the investigation included a purposive sample of participants from a single geographical metropolitan location in a developed nation with high quality public healthcare services. People without access to similar healthcare services may have had different types and severity of life impacts following an ankle fracture than participants in this investigation. However, the inclusion of participants with a range of time since injury from early post fracture to greater than two years has also helped ensure representation of impacts across the continuum of recovery. This is also likely to have mitigated the potential influence of recall bias on the subsequent framework development by including patients who have recent memories of impacts at each stage of the recovery [73].

The patient interviews were conducted by a single researcher with a clinical background. This researcher's clinical background may have inadvertently influenced the topic and nature of the interview. However, the semi-structured interview design provided some protection from this potential source of bias. The thematic analysis was also conducted by researchers familiar with common socio-demographic and clinical themes who were also aware of the potential for this framework to be used as a foundation for the subsequent development of a patient-reported outcome measure. This may have inadvertently influenced the way data was coding into categories and the grouping of categories into themes. However, the use of two independent coders, with a third researcher available to arbitrate any unresolved disagreement helped protect against this risk.

The inclusion of health professionals who have seen many patients with ankle fractures has provided additional strength to the investigation. The inclusion of only one health professional from three of the four included health disciplines may be considered a weakness of the investigation. However, on the other hand, health professionals were not the focus of this investigation, but were included to lend weight to (or refute) the validity of the thematic framework developed from patient responses. The health professionals that were included may have been more likely than patients to report an infrequent but severe life impact given their greater exposure to ankle fracture cases in comparison to patient participants. The investigators considered that the echoing of patient-reported life impacts by health professionals, without the addition of new categories based on health professional experiences, did lend weight to the thematic framework that was developed from patient responses (Table 3).

\section{Future research}

A high priority for future research is the development and validation of an ankle fracture condition-specific outcome measure. The thematic framework from this investigation will be used as stimulus material for a questionnaire framework from which specific question items and response formats could be operationalised using a staged Delphi panel process or other suitable method. The content of this measure may include questions with Likert or multiple choice response options that allow patients to report the severity of impact (or absence of impact) across the categories and themes reported in the framework. Findings from this study indicate questions to be included in this measure should extend beyond physical impacts alone and include the broad range of impacts presented in the thematic framework (Table 3). Pending appropriate pretesting and psychometric evaluation, this outcome measure could have potential use as a self-completed questionnaire suitable for use in a variety of clinical and research settings; particularly to evaluate the success (or otherwise) of rehabilitation following ankle fractures. The breadth of impacts assessed may result in this measure having potential utility for indicating when a referral to an additional health discipline (or multi-disciplinary team) is warranted.

Future research should also include investigations to examine the nature of relationships between anatomical structures included in the ankle fracture and the nature of life impacts experienced, as well as the association between physical impairment routinely evaluated in clinical practice and the broader life impacts (such as depression). 
This line of research is likely to indicate whether more holistic interventions are required, or whether current models of care focusing on restoration of ankle physical functioning are adequate.

\section{Conclusions}

The nature of life impact following ankle fractures can extend beyond short term pain and discomfort into many areas of life. The findings from this research have provided an empirically derived framework from which a condition-specific patient-reported outcome measure can be developed.

\section{Competing interests}

The authors declare they have no competing interests.

\section{Authors' contributions}

SM contributed to research idea conception, data analysis and manuscript preparation, as well as manuscript review, appraisal and editing. JD and JC contributed to data analysis and manuscript preparation. TH contributed to research idea conception, data analysis as well as manuscript review, appraisal and editing. All authors read and approved the final manuscript.

\section{Acknowledgements}

SM and TH are supported by National Health and Medical Research Council Career Awards. This research was supported by the Princess Alexandra Hospital Foundation.

\section{Author details}

${ }^{1}$ Centre for Functioning and Health Research, Metro South Health, Buranda Plaza, Corner Ipswich Road and Cornwall Street Buranda, Brisbane, Australia ${ }^{2}$ School of Public Health \& Social Work and Institute of Health and Biomedical Innovation, Queensland University of Technology, Kelvin Grove, Brisbane, Australia. ${ }^{3}$ Department of Physiotherapy, Princess Alexandra Hospital, Ipswich Road, Brisbane, Australia. ${ }^{4}$ Department of Physiotherapy, Monash University, Frankston, Australia. ${ }^{5}$ Southern Health, Allied Health Research Unit, Cheltenham, Australia.

Received: 21 December 2011 Accepted: 11 November 2012 Published: 21 November 2012

\section{References}

1. Coyte PC, Asche CV, Croxford R, Chan B: The economic cost of musculoskeletal disorders in Canada. Arthritis Rheum 1998, 11(5):315-325.

2. Praemer A, Furner S, Rice DP, Surgeons AA: Musculoskeletal conditions in the United States. IL: American Academy of Orthopaedic Surgeons Park Ridge; 1992.

3. Stewart WF, Ricci JA, Chee E, Morganstein D, Lipton R: Lost productive time and cost due to common pain conditions in the US workforce. JAMA 2003, 290(18):2443-2454.

4. Woolf $A D$, Pfleger B: Burden of major musculoskeletal conditions. Bull World Health Organ 2003, 81(9):646-656.

5. Yelin E: Cost of musculoskeletal diseases: impact of work disability and functional decline. J Rheumato/ 2003, 68:8-11.

6. Christey GR, Tomlinson M: Risk factors for ankle fracture requiring operative fixation. Aust N Z J Surg 1999, 69(3):220-223.

7. Lash N, Horne G, Fielden J, Devane P: Ankle fractures: functional and lifestyle outcomes at 2 years. Aust N Z J Surg 2002, 72(10):724-730.

8. Ponzer S, Nasell H, Bergman B, Tornkvist H: Functional outcome and quality of life in patients with Type B ankle fractures: a two-year follow-up study. J Orthop Traumatol 1999, 13(5):363-368.

9. van der Sluis CK, Eisma WH, Groothoff JW, ten Duis HJ: Long-term physical, psychological and social consequences of a fracture of the ankle. Injury 1998, 29(4):277-280.

10. Ahlborg HG, Rosengren BE, Jarvinen $T L$, Rogmark C, Nilsson JA, Sernbo I, Karlsson MK: Prevalence of osteoporosis and incidence of hip fracture in women-secular trends over 30 years. BMC Musculoskelet Disord 2010, $11: 48$
11. Den Hartog D, Van Lieshout EM, Tuinebreijer WE, Polinder S, Van Beeck EF, Breederveld RS, Bronkhorst MW, Eerenberg JP, Rhemrev S, Roerdink WH, et al Primary hemiarthroplasty versus conservative treatment for comminuted fractures of the proximal humerus in the elderly (ProCon): a multicenter randomized controlled trial. BMC Musculoskelet Disord 2010, 11:97.

12. Goldhahn S, Kralinger F, Rikli D, Marent M, Goldhahn J: Does osteoporosis increase complication risk in surgical fracture treatment? A protocol combining new endpoints for two prospective multicentre open cohort studies. BMC Musculoskelet Disord 2010, 11:256

13. Hallberg I, Bachrach-Lindstrom M, Hammerby S, Toss G, Ek AC: Health-related quality of life after vertebral or hip fracture: a seven-year follow-up study. BMC Musculoskelet Disord 2009, 10:135.

14. Wu MH, Huang TJ, Cheng CC, Li YY, Hsu RW: Role of the supine lateral radiograph of the spine in vertebroplasty for osteoporotic vertebral compression fracture: a prospective study. BMC Musculoskelet Disord 2010, 11:164.

15. Stufkens SA, van den Bekerom MP, Kerkhoffs GM, Hintermann B, van Dijk CN: Long-term outcome after 1822 operatively treated ankle fractures: a systematic review of the literature. Injury 2011, 42(2):119-127.

16. Giannini S, Faldini C, Acri F, Leonetti D, Luciani D, Nanni M: Surgical treatment of post-traumatic malalignment of the ankle. Injury 2010, 41(11):1208-1211.

17. Proctor R, Wade R, Woodward Y, Pendleton N, Baldwin R, Tarrier N, Horan M, Burns A: The impact of psychological factors in recovery following surgery for hip fracture. Disabil Rehabil 2008, 30(9):716-722.

18. Olsson LE, Nystrom AE, Karlsson J, Ekman I: Admitted with a hip fracture: patient perceptions of rehabilitation. J Clin Nurs 2007, 16(5):853-859.

19. Adachi JD, Adami S, Gehlbach S, Anderson FA Jr, Boonen S, Chapurlat RD, Compston JE, Cooper C, Delmas P, Diez-Perez A, et al: Impact of prevalent fractures on quality of life: baseline results from the global longitudinal study of osteoporosis in women. Mayo Clin Proc 2010, 85(9):806-813

20. Adachi JD, loannidis G, Olszynski WP, Brown JP, Hanley DA, Sebaldt RJ, Petrie A Tenenhouse A, Stephenson GF, Papaioannou A, et al: The impact of incident vertebral and non-vertebral fractures on health related quality of life in postmenopausal women. BMC Musculoskelet Disord 2002, 3:11.

21. Hancock MJ, Herbert RD, Stewart M: Prediction of outcome after ankle fracture. J Orthop Sports Phys Ther 2005, 35(12):786-792.

22. Lindsjo U: Operative treatment of ankle fracture-dislocations. A follow-up study of 306/321 consecutive cases. Clin Orthop Relat Res 1985, 199:28-38.

23. Day GA, Swanson CE, Hulcombe BG: Operative treatment of ankle fractures: a minimum ten-year follow-up. Foot Ankle Int 2001, 22(2):102-106

24. Johnson EE, Davlin LB: Open ankle fractures The indications for immediate open reduction and internal fixation. Clin Orthop Relat Res 1993, 292:118-127

25. Beris AE, Kabbani KT, Xenakis TA, Mitsionis G, Soucacos PK, PN: Surgical treatment of malleolar fractures. A review of 144 patients. Clin Orthop Relat Res 1997, 341:90-98.

26. Nilsson G, Nyberg P, Ekdahl C, Eneroth M: Performance after surgical treatment of patients with ankle fractures - 14-month follow-up. Physiother Res Int 2003, 8(2):69-82

27. Lin CW, Moseley AM, Refshauge KM: Rehabilitation for ankle fractures in adults. Cochrane Database Syst Rev 2008, (3):CD005595.

28. Bergland $A$, Thorsen $H$, Karesen $R$ : Association between generic and disease-specific quality of life questionnaires and mobility and balance among women with osteoporosis and vertebral fractures. Aging Clin Exp Res 2011, 23(4):296-303.

29. Cook DJ, Guyatt GH, Juniper E, Griffith L, Mcllroy W, Willan A, Jaeschke R Epstein R: Interviewer versus self-administered questionnaires in developing a disease-specific, health-related quality of life instrument for asthma. J Clin Epidemiol 1993, 46(6):529-534.

30. Guyatt GH, King DR, Feeny DH, Stubbing D, Goldstein RS: Generic and specific measurement of health-related quality of life in a clinical trial of respiratory rehabilitation. J Clin Epidemiol 1999, 52(3):187-192.

31. Irvine EJ: Quality of Life-rationale and methods for developing a disease-specific instrument for inflammatory bowel disease. Scand J Gastroenterol Supp/ 1993, 199:22-27.

32. McPhail S, Lane P, Russell T, Brauer SG, Urry S, Jasiewicz J, Condie P, Haines T: Telephone reliability of the Frenchay Activity Index and EQ-5D amongst older adults. Health Qual Life Outcomes 2009, 7:48. 
33. McPhail S, Bagraith K, Schippers M, Hatton A: Use of condition specific patient reported outcome measures in clinical trials among patients with wrist osteoarthritis: A systematic review. Adv Orthop 2012, In Press.

34. Leung AS, Lam TH, Hedley AJ, Twomey LT: Use of a subjective health measure on Chinese low back pain patients in Hong Kong. Spine (Phila Pa 1976) 1999, 24(10):961-966.

35. Schoenfeld AJ, Bono CM: Measuring spine fracture outcomes: common scales and checklists. Injury 2011, 42(3):265-270.

36. Verra ML, Angst F, Staal JB, Brioschi R, Lehmann S, Aeschlimann A, de Bie RA: Differences in pain, function and coping in Multidimensional Pain Inventory subgroups of chronic back pain: a one-group pretest-posttest study. BMC Musculoskelet Disord 2011, 12:145.

37. Ostelo RWJG, de Vet HCW, Knol DL, van den Brandt PA: 24-item Roland-Morris Disability Questionnaire was preferred out of six functional status questionnaires for post-lumbar disc surgery. J Clin Epidemiol 2004, 57(3):268-276.

38. Engelberg R, Martin DP, Agel J, Obremsky W, Coronado G, Swiontkowski MF: Musculoskeletal function assessment instrument: Criterion and construct validity. J Orthop Res 1996, 14(2):182-192.

39. Alexanderson $H$, Lundberg IE, Stenstrom CH: Development of the myositis activities profile-validity and reliability of a self-administered questionnaire to assess activity limitations in patients with polymyositis/ dermatomyositis. J Rheumatol 2002, 29(11):2386-2392.

40. McPhail S, Beller E, Haines T: Physical function and health-related quality of life of older adults undergoing hospital rehabilitation: how strong is the association? J Am Geriatr Soc 2010, 58(12):2435-2437.

41. Ware J, Sherbourne C: The MOS 36-item short-form health survey (SF-36) I. Conceptual framework and item selection. Med Care 1992, 30:473-483.

42. Anderson RT, Aaronson NK, Wilkin D: Critical review of the international assessments of health-related quality of life. Qual Life Res 1993, 2(6):369-395.

43. Ghislandi S, Apolone G, Garattini L, Ghislandi I: Is EQ-5D a valid measure of HRQoL in patients with movement disorders? A comparison with SF-36 and FIM questionnaires. Eur J Health Econ 2002, 3(2):125-130.

44. Calvisi V, De Vincentiis B, Palumbo P, Padua R, Lupparelli S: Health-related quality of life in patients with anterior cruciate ligament insufficiency undergoing arthroscopic reconstruction: a practice-based Italian normative group in comorbid-free patients. J Orthop Traumatol 2008, 9(4):233-238.

45. Linde L, Sorensen J, Ostergaard M, Horslev-Petersen K, Hetland ML: Health-related quality of life: validity, reliability, and responsiveness of SF-36, 15D, EQ-5D [corrected] RAQoL, and HAQ in patients with rheumatoid arthritis. J Rheumatol 2008, 35(8):1528-1537.

46. McPhail S, Comans T, Haines T: Evidence of disagreement between patient-perceived change and conventional longitudinal evaluation of change in health-related quality of life among older adults. Clin Rehabil 2010, 24(11):1036-1044.

47. Kearney RS, Achten J, Lamb SE, Plant C, Costa ML: A systematic review of patient-reported outcome measures used to assess Achilles tendon rupture management: What's being used and should we be using it? $\mathrm{Br} J$ Sports Med 2011,

48. Mishoe SC, Maclean JR: Assessment of health-related quality of life. Respir Care 2001, 46(11):1236-1257.

49. Dawson J, Doll H, Fitzpatrick R, Jenkinson C, Carr AJ: The routine use of patient reported outcome measures in healthcare settings. BMJ 2010, 340:c186.

50. Clancy CM, Eisenberg JM: Outcomes research: measuring the end results of health care. Science 1998, 282(5387):245.

51. Anouchi YS, McShane M, Kelly F Jr, Elting J, Stiehl J: Range of motion in total knee replacement. Clin Orthop Relat Res 1996, 331:87

52. Fife RS, Brandt KD, Braunstein EM, Katz BP, Shelbourne KD, Kalasinski LA, Ryan S: Relationship between arthroscopic evidence of cartilage damage and radiographic evidence of joint space narrowing in early osteoarthritis of the knee. Arthritis Rheum 1991, 34(4):377-382.

53. Deyo RA, Battie M, Beurskens A, Bombardier C, Croft P, Koes B, Malmivara A, Roland M, Von Korff M, Waddell G: Outcome measures for low back pain research: a proposal for standardized use. Spine 1998, 23(18):2003.

54. Mokkink LB, Terwee CB, Patrick DL, Alonso J, Stratford PW, Knol DL, Bouter LM, de Vet HC: The COSMIN study reached international consensus on taxonomy, terminology, and definitions of measurement properties for health-related patient-reported outcomes. J Clin Epidemiol 2010, 63(7):737-745.
55. Mokkink LB, Terwee CB, Patrick DL, Alonso J, Stratford PW, Knol DL, Bouter LM, de Vet HC: The COSMIN checklist for assessing the methodological quality of studies on measurement properties of health status measurement instruments: an international Delphi study. Qual Life Res 2010, 19(4):539-549.

56. Lin CW, Moseley AM, Refshauge KM: Effects of rehabilitation after ankle fracture: a Cochrane systematic review. Eur J Phys Rehabil Med 2009, 45(3):431-441.

57. Mazur JM, Schwartz E, Simon SR: Ankle arthrodesis Long-term follow-up with gait analysis. J Bone Joint Surg Am 1979, 61(7):964-975.

58. Wetzler M, Whitelaw G, Lee P: The post-operative management of ankle fractures with pneumatic braces versus short leg cast. Orthop Trans 1991, 15:719.

59. DiStasio AJ 2nd, Jaggears FR, DePasquale LV, Frassica FJ, Turen CH: Protected early motion versus cast immobilization in postoperative management of ankle fractures. Contemp Orthop 1994, 29(4):273-277.

60. Moseley AM, Herbert RD, Nightingale EJ, Taylor DA, Evans TM, Robertson GJ, Gupta SK, Penn J: Passive stretching does not enhance outcomes in patients with plantarflexion contracture after cast immobilization for ankle fracture: a randomized controlled trial. Arch Phys Med Rehabil 2005, 86(6):1118-1126.

61. Brink O, Staunstrup $H$, Sommer J: Stable lateral malleolar fractures treated with aircast ankle brace and DonJoy R.O.M.-Walker brace: a prospective randomized study. Foot Ankle Int 1996, 17(11):679-684

62. Finsen V, Saetermo R, Kibsgaard L, Farran K, Engebretsen L, Bolz KD Benum P: Early postoperative weight-bearing and muscle activity in patients who have a fracture of the ankle. J Bone Joint Surg Am 1989, 71(1):23-27.

63. Olerud C, Molander $\mathrm{H}$ : A scoring scale for symptom evaluation after ankle fracture. Arch Orthop Trauma Surg 1984, 103(3):190-194.

64. Eechaute C, Vaes P, Van Aerschot L, Asman S, Duquet W: The clinimetric qualities of patient-assessed instruments for measuring chronic ankle instability: a systematic review. BMC Musculoskelet Disord 2007, 8:6.

65. Binkley JM, Stratford PW, Lott SA, Riddle DL: The Lower Extremity Functional Scale (LEFS): scale development, measurement properties, and clinical application. North American Orthopaedic Rehabilitation Research Network. Phys Ther 1999, 79(4):371-383.

66. Stratford PW, Kennedy DM, Hanna SE: Condition-specific Western Ontario McMaster Osteoarthritis Index was not superior to region-specific Lower Extremity Functional Scale at detecting change. J Clin Epidemiol 2004, 57(10):1025-1032.

67. Watson CJ, Propps M, Ratner J, Zeigler DL, Horton P, Smith SS: Reliability and responsiveness of the lower extremity functional scale and the anterior knee pain scale in patients with anterior knee pain. J Orthop Sports Phys Ther 2005, 35(3):136-146.

68. Lin CW, Moseley AM, Refshauge KM, Bundy AC: The lower extremity functional scale has good clinimetric properties in people with ankle fracture. Phys Ther 2009, 89(6):580-588.

69. Yeung TS, Wessel J, Stratford P, Macdermid J: Reliability, validity, and responsiveness of the lower extremity functional scale for inpatients of an orthopaedic rehabilitation ward. J Orthop Sports Phys Ther 2009, 39(6):468-477

70. Maykut P, Maykut PS, Morehouse RE, Morehouse R: Beginning qualitative research: A philosophic and practical guide, vol. 6. London, UK: Routledge; 1994.

71. Patton MQ: Qualitative research and evaluation methods. London, UK: Sage Publications, Inc; 2002

72. Gunn J, Diggens J, Hegarty K, Blashki G: A systematic review of complex system interventions designed to increase recovery from depression in primary care. BMC Health Serv Res 2006, 6:88.

73. McPhail S, Haines T: Response shift, recall bias and their effect on measuring change in health-related quality of life amongst older hospital patients. Health Qual Life Outcomes 2010, 8(1):65.

doi:10.1186/1471-2474-13-224

Cite this article as: McPhail et al.: Life impact of ankle fractures:

Qualitative analysis of patient and clinician experiences. BMC

Musculoskeletal Disorders 2012 13:224. 